\title{
In silico analysis of binding interaction of conantokins with NMDA receptors for potential therapeutic use in Alzheimer's disease
}

\author{
Maleeha Waqar and Sidra Batool
}

\begin{abstract}
Background: The N-methyl-D-aspartate (NMDA) receptors are glutamate receptors that play vital roles in central nervous system development and are involved in synaptic plasticity, which is an essential process for learning and memory. The subunit N-methyl D-aspartate receptor subtype 2B (NR2B) is the chief excitatory neurotransmitter receptor in the mammalian brain. Disturbances in the neurotransmission mediated by the NMDA receptor are caused by its overexposure to glutamate neurotransmitter and can be treated by its binding to an antagonist. Among several antagonists, conantokins from cone snails are reported to bind to NMDA receptors.
\end{abstract}

Methods: This study was designed to analyze the binding mode of conantokins with NMDA receptors in both humans and rats. To study interactions, dockings were performed using AutoDock 4.2 and their results were further analyzed using various computational tools.

Results: Detailed analyses revealed that these ligands can bind to active site residues of both receptors as reported in previous studies.

Conclusions: In light of the present results, we suggest that these conantokins can act as antagonists of those receptors and play an important role in understanding the importance of inhibition of NMDA receptors for treatment of Alzheimer's disease.

Keywords: N-methyl-D-aspartate, Glutamate, Synaptic plasticity, NR2B, Neurotransmitter, Antagonists, Conantokins, Docking, In silico, Alzheimer's dieases

\section{Background}

The N-methyl-D-aspartate (NMDA) receptors are inotropic glutamate receptors that are gated cation channels $[1,2]$. The NMDA receptors (NMDAR) play vital roles in central nervous system (CNS) development [2]. These receptors are highly permeable to $\mathrm{Ca}^{2+}$ ions and the calcium flux is critically important for synaptic plasticity, which is an essential neurochemical process for learning and memory [2-4]. The receptor itself has many subunits and their variants have numerous functions in the brain. The subunit N-methyl-D-aspartate receptor subtype 2B (NR2B) is the chief excitatory neurotransmitter

\footnotetext{
* Correspondence: sidra.batool@comsats.edu.pk

Department of Biosciences, COMSATS Institute of Information Technology, Park Road, Chak Shahzad, Islamabad 45550, Pakistan
}

receptor in the mammalian brain [5]. The glutamate neurotransmitter allows for a transmembrane ion flow through the receptor to increase the action potential of the neuron. This characteristic makes the synapsis among these neurons to be the main memory storage unit and hence associates them with learning and memory [6]. Due to their functioning in the CNS, the potential of these receptors as drug targets for various neurodegenerative diseases has been highlighted in the literature.

NMDAR antagonists have emerged as potential lead compounds for Alzheimer's patients [7]. The cognitive symptoms associated with deficits in learning and menory have been attributed to disturbances in glutaminergic neurotransmission [8]. The excessive stimulation by the glutamate neurotransmitter of neurons causes excitotoxicity and 


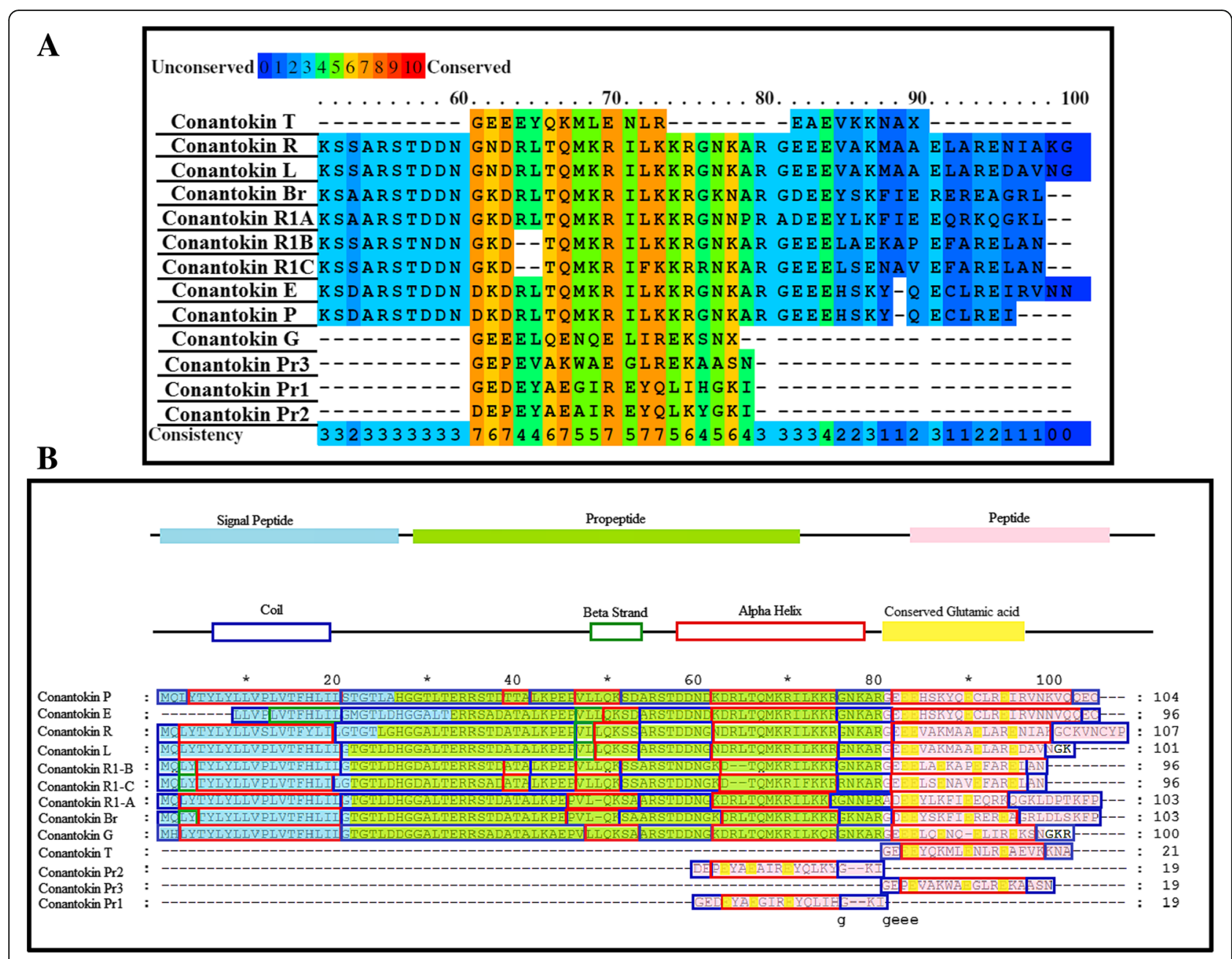

Fig. 1 a Conserved residues highlighted in conantokins. b Predicted secondary structures of all conantokins aligned

results in damage and death of neurons [8]. Blocking the glutaminergic neurotransmission mediated by NMDA receptors can alleviate the excitotoxicity and prevent further neuron damage and death.

Several venom toxins have made their way in scientific studies and clinical trials for their therapeutic potential against various diseases. Having mostly inhibitory effects, these toxin peptides target different receptors across the body, the hyperactivity of which is associated with the pathophysiology of many diseases. Numerous toxins have been reported to target and block receptors used for the treatment of Alzheimer's disease, such as neurotoxins that target acetylcholinesterase enzymes and certain toxins from Mamba snakes that were reported to inhibit the muscarinic acetylcholine receptors $[9,10]$. A few toxins with antagonistic properties against NMDA receptor have been reported as well. The conantokins are powerful and potent blockers of the NMDA receptor, with particularly high selectivity for the NR2B subunit [11]. These toxins have been reported to block these glutamine receptors and therefore have therapeutic potential for treating Alzheimer's disease.

The objective of this study was to perform and look into the in silico analysis of the binding interaction of conantokins with the NMDA receptor NR2B subunit. The mode of interaction and the binding residues for both the ligand dataset and the receptor dataset were collected. Due to unavailability of the crystal structures of the NMDA receptor in humans and most of conantokins, their three-

Table 1 Docking parameters used for docking studies on AutoDock 4.2

\begin{tabular}{llll}
\hline Grid Parameters & \multicolumn{3}{l}{ Docking Parameters } \\
\hline Spacing & $0.375 \AA$ & Energy evaluations & $2.5 \times 10^{6}$ \\
Grid center & $80 \mathrm{X}$ & Iterations & 27,000 \\
& $80 Y \AA$ & Mutation rate & 0.02 \\
& $80 Z \AA$ & Crossover rate & 0.80 \\
& & Elitism value & 1 \\
& & RMS Tolerance & $1.0 \AA$ \\
\hline
\end{tabular}




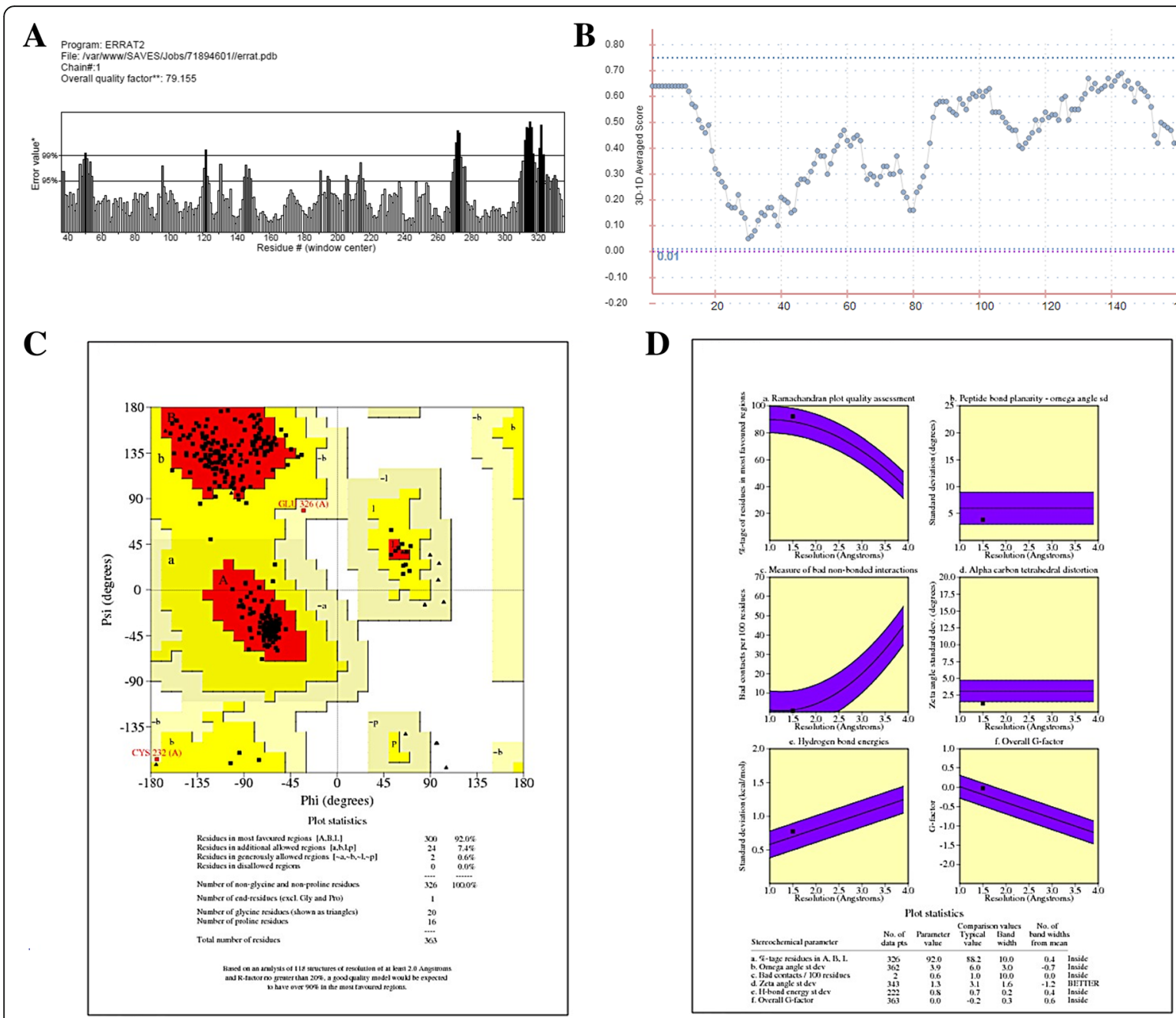

Fig. 2 Validation results for the predicted structure of NMDAR in humans. a Graphical representation of results from ERRAT. b Graphical representation of results from Verify_3D. c Ramachandran Plot for NMDAR (humans). d Main chain parameters

dimensional structures were predicted via computational homology modeling methods and the predicted models were validated to continue their further use.

Docking studies provided insights into binding pattern of receptors and ligands. A number of in silico studies investigated many computational approaches ranging from construction of structural models to investigation and discovery of potential drug candidates [12-14]. The analysis of the binding interactions of the receptor and the ligand peptides produced results that helped us demonstrate the pharmacological importance of conantokins and their potential use as NMDA receptor antagonists for treatment of Alzheimer's disease.

\section{Methods}

\section{Receptor dataset collection}

The first step of methodology included collection of receptor proteins. As the structure of NMDA receptor in humans is not available, it had to be predicted via computational homology modeling, which allowed the construction of a threedimensional structure of a protein based on the known structures of similar protein templates. SWISS-MODEL was used for this purpose, as it is a fully automated protein structure homology modeling server [15]. The protein template used for structure prediction of NMDAR in humans was the structure of NMDAR in Rattus norvegicus (brown rat) [16]. The structure of the template (pdb id: 3JPW) was retrieved from the Research Collaboratory for Structural Bioinformatics (RSCB) [17]. After structure prediction, the Structure Analysis and Verification Server (SAVES) was used for validation by generating Ramachandran plot [18] and ERRAT [19], which gives a factor of overall quality of the predicted structure. Whereas Verify_3D [20] was employed to analyze the compatibility of the atomic model of the protein with its own amino acid sequence. 


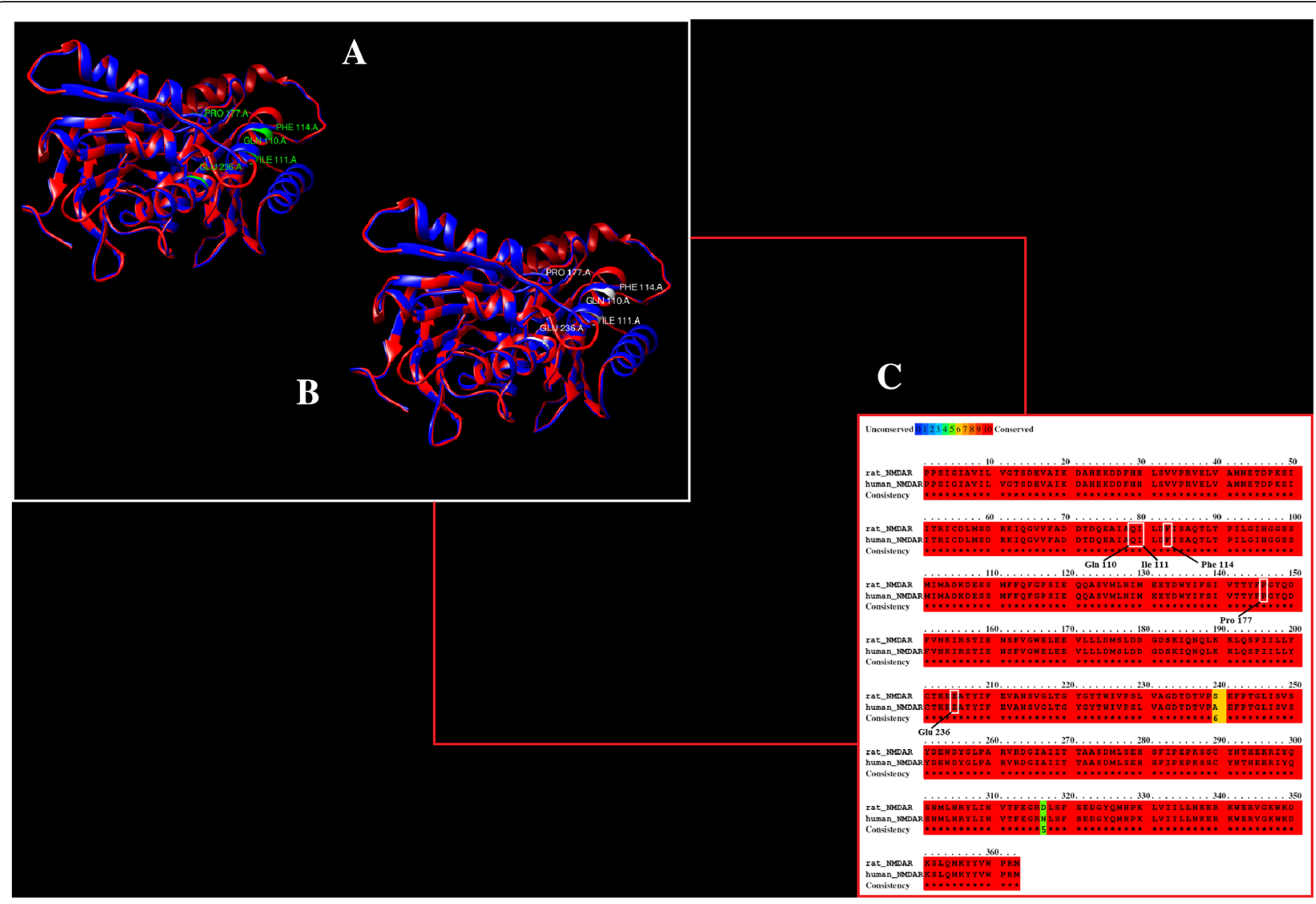

Fig. 3 a NMDAR in humans (red) active residues highlighted in green. b NMDAR in rats (blue) residues aligned with residues of NMDAR in humans highlighted in white. c Conserved residues shown in sequence alignment between the NMDA receptor in rats (above) and humans (below)

\section{Ligand dataset collection}

The ligand dataset comprised reported conantokins that are a class of conopeptides (17-27 amino acids) without cysteine residues that selectively influence NMDA receptors [21]. Among them, only three-dimensional structures of conantokin $\mathrm{G}$ and conantokin $\mathrm{T}$ are available on Protein Data Bank (PDB ID: 1ONU and 1ONT, respectively). The crystal structures of other conantokins $\mathrm{Br}, \mathrm{L}$, P, R, E, Pr1, Pr2, Pr3, R1A, R1B and R1C are not available on the Protein Data Bank and therefore were subjected to three-dimensional structure prediction. Homology modeling was used initially, but due to absence of any homologues for the conantokins, the structure prediction was carried out via fold recognition (threading) on the Iterative Threading ASSEmbly Refinement (iTASSER) server [22], which detects structure templates from the Protein Data Bank and constructs full-length structure models by reassembling structural fragments from threading templates. The predicted structures were then validated on the SAVES metaserver using Procheck, ERRAT and Verify_3D. Multiple sequence alignment (MSA) using PRALINE [23] multiple sequence alignment toolbox was performed on all the conantokins to find out residues and secondary structure conservation. The residues responsible for the signal peptides, peptide precursors and active protein peptides were also highlighted for each conantokin showing considerable conservation in these peptide regions as well, as shown in Fig. 1.

The conserved glutamic acid residues in each conantokin are the positions for residue modification, where the glutamic acid is converted to 4-carboxyglutamate. Sufficient conservation of secondary structures was observed among all the conantokins.

\section{Experimental background reported for conantokins and NMDAR}

Conantokins have been the subject of interest for their potential as NMDA receptor antagonists in studying many neuropathologies. Wet lab experiments have been conducted to understand the basis for interaction between conantokins and NMDA receptor. These wet lab techniques were carried out using NMDA receptors in rats by employing electrophysiological techniques to understand the diversity in the functioning of these toxins [24]. Techniques such as polyamine enhancement 
Table 2 Docking results of conantokin ligands in complex with NMDA receptor in humans

\begin{tabular}{|c|c|c|c|c|c|c|}
\hline \multirow[t]{2}{*}{ Conantokin } & \multicolumn{4}{|l|}{ Hydrogen bonds } & \multicolumn{2}{|c|}{ Hydrophobic bonds } \\
\hline & Receptor residues & Ligand residues & Distance $(\AA)$ & Atoms & Receptor residues & Ligand residues \\
\hline Conantokin G & - & - & - & - & $\begin{array}{l}\text { Glu236 } \\
\text { Gln110 } \\
\text { Phe114 } \\
\text { lle111 } \\
\text { Pro177 }\end{array}$ & $\begin{array}{l}\text { Ile12 } \\
\text { Leu5 } \\
\text { Ser16 } \\
\text { Gln9 }\end{array}$ \\
\hline Conantokin L & Gln110 & $\begin{array}{l}\text { Asp96 } \\
\text { Ala93 } \\
\text { Leu65 }\end{array}$ & $\begin{array}{l}2.36 \\
2.25 \\
2.81\end{array}$ & $\begin{array}{l}\text { N-OD1 } \\
\text { OE1-N } \\
\text { NE2-O }\end{array}$ & $\begin{array}{l}\text { Pro177 } \\
\text { lle111 } \\
\text { Glu236 } \\
\text { Phe114 }\end{array}$ & $\begin{array}{l}\text { Met88 } \\
\text { Thr24 } \\
\text { Val85 } \\
\text { Gly81 }\end{array}$ \\
\hline Conantokin E & $\begin{array}{l}\text { Pro177 } \\
\text { Glu236 }\end{array}$ & $\begin{array}{l}\text { Arg67 } \\
\text { Asp18 } \\
\text { Gly13 } \\
\text { Gly12 }\end{array}$ & $\begin{array}{l}3.09 \\
2.32 \\
2.23 \\
3.19\end{array}$ & $\begin{array}{l}\text { O-NH1 } \\
\text { OE2-N } \\
\mathrm{N}-\mathrm{O} \\
\text { OE2-N }\end{array}$ & $\begin{array}{l}\text { lle111 } \\
\text { Phe114 } \\
\text { Gln110 }\end{array}$ & $\begin{array}{l}\text { Leu41 } \\
\text { Gln59 } \\
\text { Lys66 }\end{array}$ \\
\hline Conantokin Pr1 & Glu236 & $\mathrm{Gln} 13$ & 3.13 & OE2-NE2 & $\begin{array}{l}\text { Pro177 } \\
\text { Gln110 }\end{array}$ & $\begin{array}{l}\text { Asp3 } \\
\text { Ala6 }\end{array}$ \\
\hline Conantokin Pr2 & Glu236 & Lys15 & 3.11 & OE2-NZ & $\begin{array}{l}\text { Gn110 } \\
\text { lle111 } \\
\text { Phe114 }\end{array}$ & $\begin{array}{l}\text { Glu4 } \\
\text { Ala8 } \\
\text { Tyr5 }\end{array}$ \\
\hline Conantokin Pr3 & - & - & - & - & $\begin{array}{l}\text { Gln110 } \\
\text { lle111 } \\
\text { Phe114 } \\
\text { Pro177 }\end{array}$ & $\begin{array}{l}\text { Glu2 } \\
\text { Gly1 } \\
\text { Glu4 } \\
\text { Trp8 }\end{array}$ \\
\hline Conantokin $\mathrm{T}$ & $\begin{array}{l}\text { Glu236 } \\
\text { Gln110 }\end{array}$ & $\begin{array}{l}\text { Arg13 } \\
\text { Gln6 }\end{array}$ & $\begin{array}{l}2.85,2.92 \\
2.88\end{array}$ & $\begin{array}{l}\text { OE2-NH2 } \\
\text { OE2-NE } \\
\text { OE1-NE2 }\end{array}$ & Ile111 & Glu16 \\
\hline Conantokin R1A & $\begin{array}{l}\text { Glu236 } \\
\text { Gln110 }\end{array}$ & $\begin{array}{l}\text { Arg54 } \\
\text { Asp58 }\end{array}$ & $\begin{array}{l}2.70 \\
2.82\end{array}$ & $\begin{array}{l}\mathrm{O}-\mathrm{NH} 1 \\
\mathrm{~N}-\mathrm{O}\end{array}$ & $\begin{array}{l}\text { lle111 } \\
\text { Phe114 } \\
\text { Pro177 }\end{array}$ & $\begin{array}{l}\text { Leu13 } \\
\text { Leu18 } \\
\text { Glu33 }\end{array}$ \\
\hline Conantokin R1B & Gln110 & Tyr8 & 3.22 & $\mathrm{~N}-\mathrm{OH}$ & $\begin{array}{l}\text { Ile111 } \\
\text { Pro177 } \\
\text { Glu236 }\end{array}$ & $\begin{array}{l}\text { Lys62 } \\
\text { Lys71 } \\
\text { Ala95 }\end{array}$ \\
\hline Conantokin R1C & Gln110 & Val11 & 2.06 & NE2-O & $\begin{array}{l}\text { Glu236 } \\
\text { lle111 } \\
\text { Pro177 } \\
\text { Phe114 }\end{array}$ & $\begin{array}{l}\text { Asp77 } \\
\text { Ala39 } \\
\text { Pro12 } \\
\text { Leu13 }\end{array}$ \\
\hline Conantokin R & $\begin{array}{l}\text { Glu236 } \\
\text { Phe114 }\end{array}$ & $\begin{array}{l}\text { Gln50 } \\
\text { Ala98 }\end{array}$ & $\begin{array}{l}3.33 \\
2.01\end{array}$ & OE2-NE2 N-O & $\begin{array}{l}\text { le111 } \\
\text { Pro177 } \\
\text { Gln110 }\end{array}$ & $\begin{array}{l}\text { Ser52 } \\
\text { Leu65 } \\
\text { Met68 }\end{array}$ \\
\hline Conantokin $\mathrm{Br}$ & $\mathrm{G} \ln 110$ & Ala94 & 1.93 & NE2-O & $\begin{array}{l}\text { Pro177 } \\
\text { lle111 } \\
\text { Glu236 }\end{array}$ & $\begin{array}{l}\text { Thr22 } \\
\text { lle82 } \\
\text { Asp77 }\end{array}$ \\
\hline Conantokin P & Glu236 & Leu65 & 2.33 & $\mathrm{~N}-\mathrm{OE} 2$ & $\begin{array}{l}\text { Gln110 } \\
\text { lle111 } \\
\text { Phe114 } \\
\text { Pro177 }\end{array}$ & $\begin{array}{l}\text { Arg80 } \\
\text { Glu45 } \\
\text { Lys43 } \\
\text { Val47 }\end{array}$ \\
\hline
\end{tabular}

and NMR spectroscopy have allowed the understanding of how similar the inhibition of NMDAR by conantokins in humans is to previously reported inhibition of NMDAR in rats by conantokins [25]. Using chemically synthesized conantokin variants (created by techniques of point mutation and chimeric proteins), the subtype selectivity of NMDAR has been extensively studied for most conantokins [26]. In addition, conantokins represent a class of NMDA antagonists with an improved safety profile compared to other antagonists that show psychotomimetic, amnesic and motor-impairing actions and neurotoxicity, which limit their usefulness in humans [21]. These wet lab studies revealed the pharmacological importance of conantokins as antagonists of NMDAR for their therapeutic applications in many neuropathologies and have led us to investigate this property computationally.

\section{Docking studies}

Molecular dockings are performed to predict the binding orientation between a receptor and its ligand to form a 


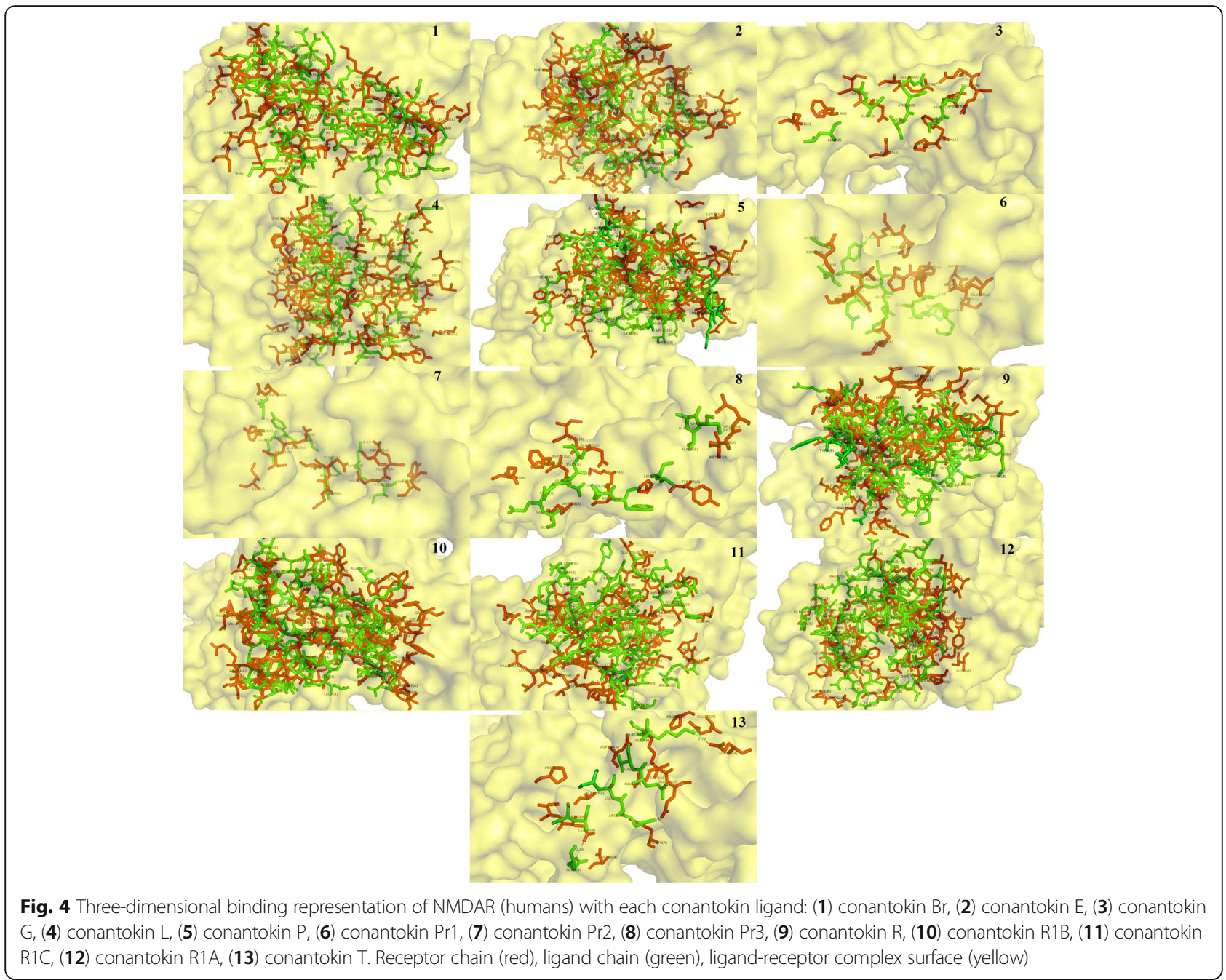

stable molecular complex [27]. This allows a detailed insight of the three-dimensional structure formed between two biomolecules and to correlate this information to find a potential drug candidate for these receptors [28]. Molecular docking was performed for NMDA receptors for both humans and rats. AutoDock 4.2 [29] was used to perform automated docking runs, in order to find the binding mode of each receptor with each conantokin ligand. The number of runs for each docking was set to 50 to allow each ligand 50 different conformations with the receptors in order to let them bind freely anywhere on the receptor. The grid size was set to cover the entire receptor in order to find a potential binding site for each ligand and to analyze if each ligand indeed occupies the site on the receptor that is crucial for its functioning in Alzheimer's and could potentially inhibit it. The docking parameters used are shown in Table 1.

Post-docking analysis of the results was carried out on AutoDock 4.2 and later visualized on Chimera [30].
Ligplot $^{+}$[31] was used for further validation of the protein-protein interactions, which generates twodimensional schematics on the basis of hydrogen bonds and hydrophobic interactions. The three-dimensional structural analysis was performed on PyMol [32] that allowed the residues in the protein-protein interaction of the receptor-ligand complex to be highlighted. The energy of each complex that was achieved via docking allowed the receptor-ligand bindings to be confirmed and refined and used for further analysis and results discussion.

\section{Results and discussion}

Structure prediction and validation of NMDAR in human

The predicted three-dimensional structure of the NMDA receptor in humans was superimposed on Chimera with its template, a NMDA receptor in rat yielding a root mean square deviation (RSMD) of $0.181 \AA$ A . In addition, the results for structure evaluation proved the quality of the predicted structure. As 


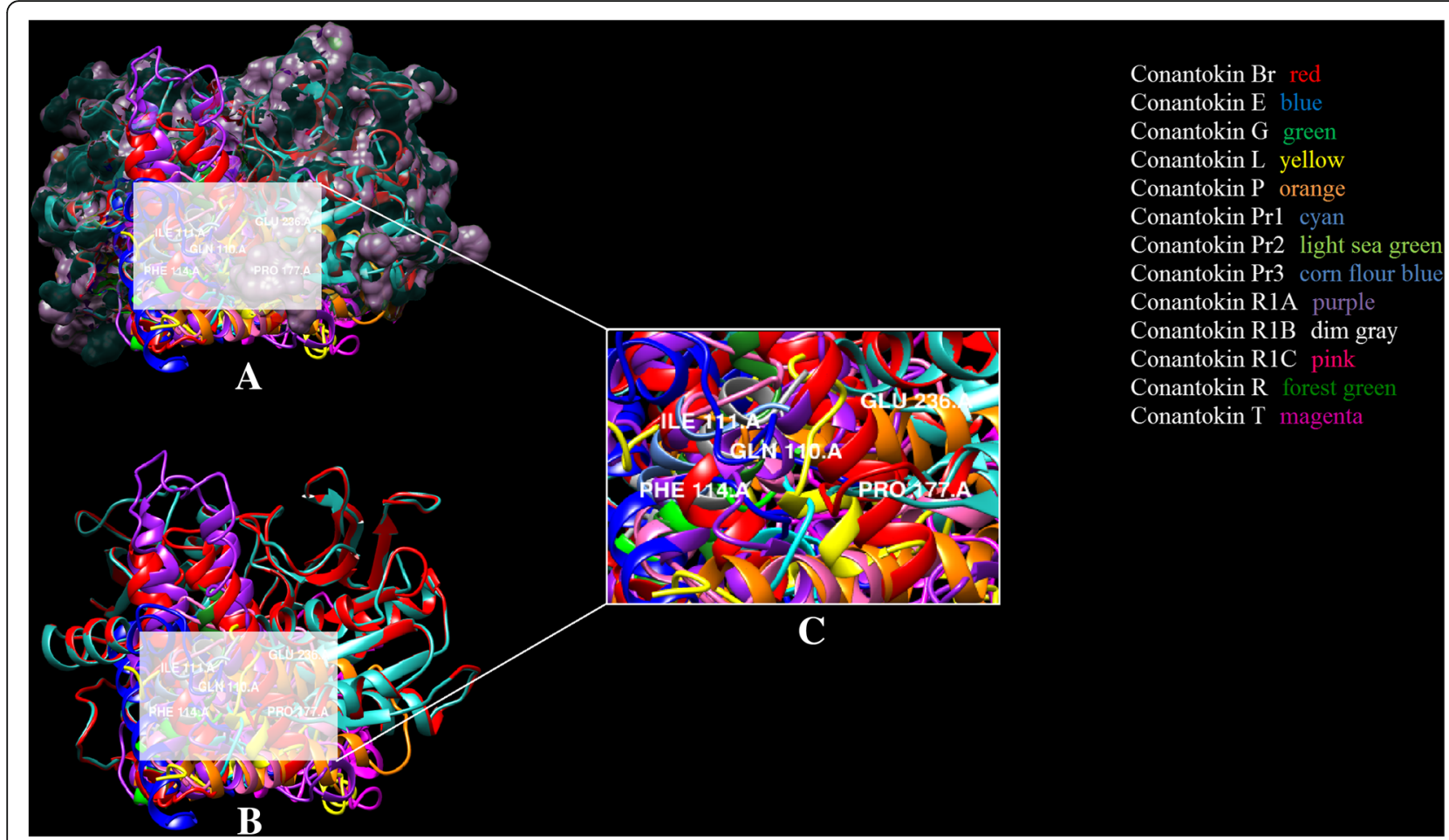

Fig. 5 a Conantokins in complex with the NMDAR (humans). b Active residues in the binding pocket highlighted (white) of the NMDAR with conantokin ligands. c Binding pocket highlighted and focused. Three-dimensional binding representation of all toxins from the ligand dataset: conantokin $\mathrm{Br}$ (red), conantokin E (blue), conantokin G (green), conantokin L (yellow), conantokin P (orange), conantokin Pr1 (cyan), conantokin Pr2 (light sea green), conantokin Pr3 (cornflour blue), conantokin R1A (purple), conantokin R1B (dim gray), conantokin R1C (pink), conantokin R (forest green), conantokin T (magenta) with the NMDA receptor in human

indicated by the Ramachandran plot, $92 \%$ of the residues were in favored regions. Moreover, the main chain parameters such as peptide bond planarity, measure of non-bonded interactions, $\alpha$ carbon tetrahedral distortion, $\mathrm{H}$-bond energy and overall $\mathrm{G}$ factor for the structure were found within favorable regions. ERRAT and Verify_3D further validated the structure by scoring it with an overall quality factor of 79.155 and by passing it with $80 \%$ of the amino acids having scored $\geq 0.2$ respectively (Fig. 2). The validation results suggested that the predicted model of the NMDA receptor in humans was of good quality and can be used for further analysis.

\section{Structure prediction and validation of conantokins}

The predicted structure of each conantokin was also validated in order to check the quality of their threedimensional structures. All predicted structures were passed by Ramachandran plot, ERRAT and Verify_3D, suggesting that these structures were of good quality and could be used further study.

\section{Binding site residue information}

After structure prediction and evaluation, binding site residue information for NMDA receptor in humans was gathered. Since this is a computational based analysis, it is very important to identify binding site residues correctly and verify the results. As no previous information for binding residues of NMDAR in humans was reported, the binding site was retrieved by using the binding site residues of NMDAR reported in the literature that showed residues specific for the NR2B subunit in rats. The two structures were aligned and it was observed that the binding site residues reported for NMDAR in rats are conserved in humans. The binding residues for NMDAR in both humans and rats are shown in Fig. 3. These identified residues have been taken as references to further evaluate the docking results.

Binding residue information for conantokin $G$ only suggests Glu2, Gln6, Asn8, Arg13, Asn17 and Lys15 as predominant residues that are involved in interactions with the NMDAR subtype selectivity for NR2B subunit. Moreover, the first five amino acids of conantokins, especially Glu2 and Gla4 and a hydrophobic residue at position 12 are critical for functional activity in vitro [21]. It has been observed that the peptide region has shown importance in interactions. These residues are also found to be conserved in other conantokins as well. 
Table 3 Docking results of conantokin ligands in complex with NMDA receptor in rats

\begin{tabular}{|c|c|c|c|c|c|c|}
\hline \multirow[t]{2}{*}{ Conantokin } & \multicolumn{4}{|l|}{ Hydrogen bonds } & \multicolumn{2}{|l|}{ Hydrophobic bonds } \\
\hline & Receptor residues & Ligand residues & Distance $(\AA)$ & Atoms & Receptor residues & Ligand residues \\
\hline Conantokin G & $G \ln 110$ & $\operatorname{Arg} 13$ & 2.64 & OE1-NE & $\begin{array}{l}\text { Ile111 } \\
\text { Phe114 }\end{array}$ & $\begin{array}{l}\text { Ile12 } \\
\text { Gln9 }\end{array}$ \\
\hline Conantokin L & $\mathrm{Gln} 110$ & Pro46 & 1.52 & NE2-O & $\begin{array}{l}\text { lle111 } \\
\text { Phe114 } \\
\text { Pro177 } \\
\text { Glu236 }\end{array}$ & $\begin{array}{l}\text { Pro12 } \\
\text { Ala30 } \\
\text { Asp77 } \\
\text { Val42 }\end{array}$ \\
\hline Conantokin E & $\begin{array}{l}\text { Gln110 } \\
\text { Ile111 }\end{array}$ & $\begin{array}{l}\text { Ile11 } \\
\text { Cys83 }\end{array}$ & $\begin{array}{l}2.94 \\
1.90\end{array}$ & $\begin{array}{l}\text { OE1-N } \\
\mathrm{N}-\mathrm{O}\end{array}$ & $\begin{array}{l}\text { Phe114 } \\
\text { Pro177 } \\
\text { Glu236 }\end{array}$ & $\begin{array}{l}\text { Lys61 } \\
\text { Ser28 } \\
\text { Leu64 }\end{array}$ \\
\hline Conantokin $\operatorname{Pr} 1$ & - & - & - & - & $\begin{array}{l}\text { Glu236 } \\
\text { Phe114 } \\
\text { Pro177 } \\
\text { Gln110 }\end{array}$ & $\begin{array}{l}\text { Ile15 } \\
\text { His16 } \\
\text { Asp3 } \\
\text { Lys18 }\end{array}$ \\
\hline Conantokin Pr2 & $\mathrm{Gln} 110$ & Lys15 & 2.88 & OE1-NZ & $\begin{array}{l}\text { Glu236 } \\
\text { Pro177 } \\
\text { Phe114 }\end{array}$ & $\begin{array}{l}\text { Glu14 } \\
\text { Gly1 } \\
\text { Ala6 }\end{array}$ \\
\hline Conantokin Pr3 & $G \ln 110$ & Lys7 & 2.96 & OE1-NZ & $\begin{array}{l}\text { lle111 } \\
\text { Phe114 } \\
\text { Pro177 }\end{array}$ & $\begin{array}{l}\text { Trp8 } \\
\text { Glu2 } \\
\text { Glu4 }\end{array}$ \\
\hline Conantokin T & Glu236 & $\operatorname{Arg} 13$ & $2.69,2.71$ & $\begin{array}{l}\text { OE2-NE, } \\
\text { OE2-NH2 }\end{array}$ & Ile111 & Glu16 \\
\hline Conantokin R & $\begin{array}{l}\text { Gln110 } \\
\text { lle111 }\end{array}$ & $\begin{array}{l}\text { Lys73 } \\
\text { Lys87 }\end{array}$ & $\begin{array}{l}2.13 \\
3.35\end{array}$ & $\begin{array}{l}\text { OE1-N } \\
\text { O-NZ }\end{array}$ & $\begin{array}{l}\text { Phe114 } \\
\text { Pro177 } \\
\text { Glu236 }\end{array}$ & $\begin{array}{l}\text { Glu95 } \\
\text { Lys99 } \\
\text { Asn62 }\end{array}$ \\
\hline Conantokin R1A & $\begin{array}{l}\text { Gln110 } \\
\text { Glu236 }\end{array}$ & $\begin{array}{l}\text { Leu7, } \\
\text { Leu9, } \\
\text { Thr5 } \\
\text { Thr65 }\end{array}$ & $\begin{array}{l}2.22 \\
2.15,2.80 \\
1.79 \\
3.14\end{array}$ & $\begin{array}{l}\text { OE1-N } \\
\text { N-O, NE2-O } \\
\text { NE2-O } \\
\text { OE1-N }\end{array}$ & $\begin{array}{l}\text { lle111 } \\
\text { Phe114 } \\
\text { Pro177 }\end{array}$ & $\begin{array}{l}\text { lle19 } \\
\text { Arg63 } \\
\text { Thr56 }\end{array}$ \\
\hline Conantokin R1B & - & - & - & - & $\begin{array}{l}\text { Gln110 } \\
\text { Ile111 } \\
\text { Pro177 } \\
\text { Glu236 }\end{array}$ & $\begin{array}{l}\text { Pro12 } \\
\text { Ala77 } \\
\text { Asp63 } \\
\text { Thr76 }\end{array}$ \\
\hline Conantokin R1C & $\begin{array}{l}\text { Gln110 } \\
\text { Glu236 }\end{array}$ & $\begin{array}{l}\text { Val14 } \\
\text { Ser52 }\end{array}$ & $\begin{array}{l}2.47 \\
2.54\end{array}$ & $\begin{array}{l}\text { OE1-N } \\
\text { OE2-OG }\end{array}$ & $\begin{array}{l}\text { lle111 } \\
\text { Phe114 } \\
\text { Pro177 }\end{array}$ & $\begin{array}{l}\text { Gln65 } \\
\text { His17 } \\
\text { Leu49 }\end{array}$ \\
\hline Conantokin $\mathrm{Br}$ & $G \ln 110$ & Ala94 & 1.93 & NE2-O & $\begin{array}{l}\text { Ile111 } \\
\text { Pro177 } \\
\text { Glu236 }\end{array}$ & $\begin{array}{l}\text { Asn59 } \\
\text { lle82 } \\
\text { Asp77 }\end{array}$ \\
\hline Conantokin P & $\begin{array}{l}\text { Glu236 } \\
\text { lle111 }\end{array}$ & $\begin{array}{l}\text { Leu42, Ala41 } \\
\text { Gln89 }\end{array}$ & $\begin{array}{l}1.27,2.71 \\
3.07\end{array}$ & $\begin{array}{l}\text { OE1-N, OE1-N } \\
\text { N-O }\end{array}$ & $\begin{array}{l}\text { Gln110 } \\
\text { Phe114 } \\
\text { Pro177 }\end{array}$ & $\begin{array}{l}\text { Thr30 } \\
\text { Leu3 } \\
\text { Ser21 }\end{array}$ \\
\hline
\end{tabular}

\section{Docking results}

After structure prediction and binding site identification, molecular dockings were performed on NMDAR receptors with conantokin ligands. Docking results were run based on their energy values and were ranked as such with each run showing results for receptor-ligand complex with the lowest energy. Detailed analysis of each run for each complex showed that all the conantokins showed bindings with the conserved active sites of NMDA receptor in both humans and rats. All the conantokins seemed to bind with the glutamine and glutamic acid residues in the NMDA receptors in both humans and rats. Table 2 shows the detailed analysis retrieved from plotting the docking results on LigPlot ${ }^{+}$, showing the binding of NMDA receptor in humans with conantokins. These data include information about respective hydrogen bond residues of both receptors and ligands, their bond distances, bond atoms and the interacting hydrophobic residues.

Glutamic acid at position 236 and glutamine at position 110 were predominantly involved in the binding of the NR2B subunit of NMDAR in human with all the conantokins. Isoleucine at position 111, phenylalanine at position 114 and proline at position 177 were mostly found in hydrophobic interactions. The binding patterns 


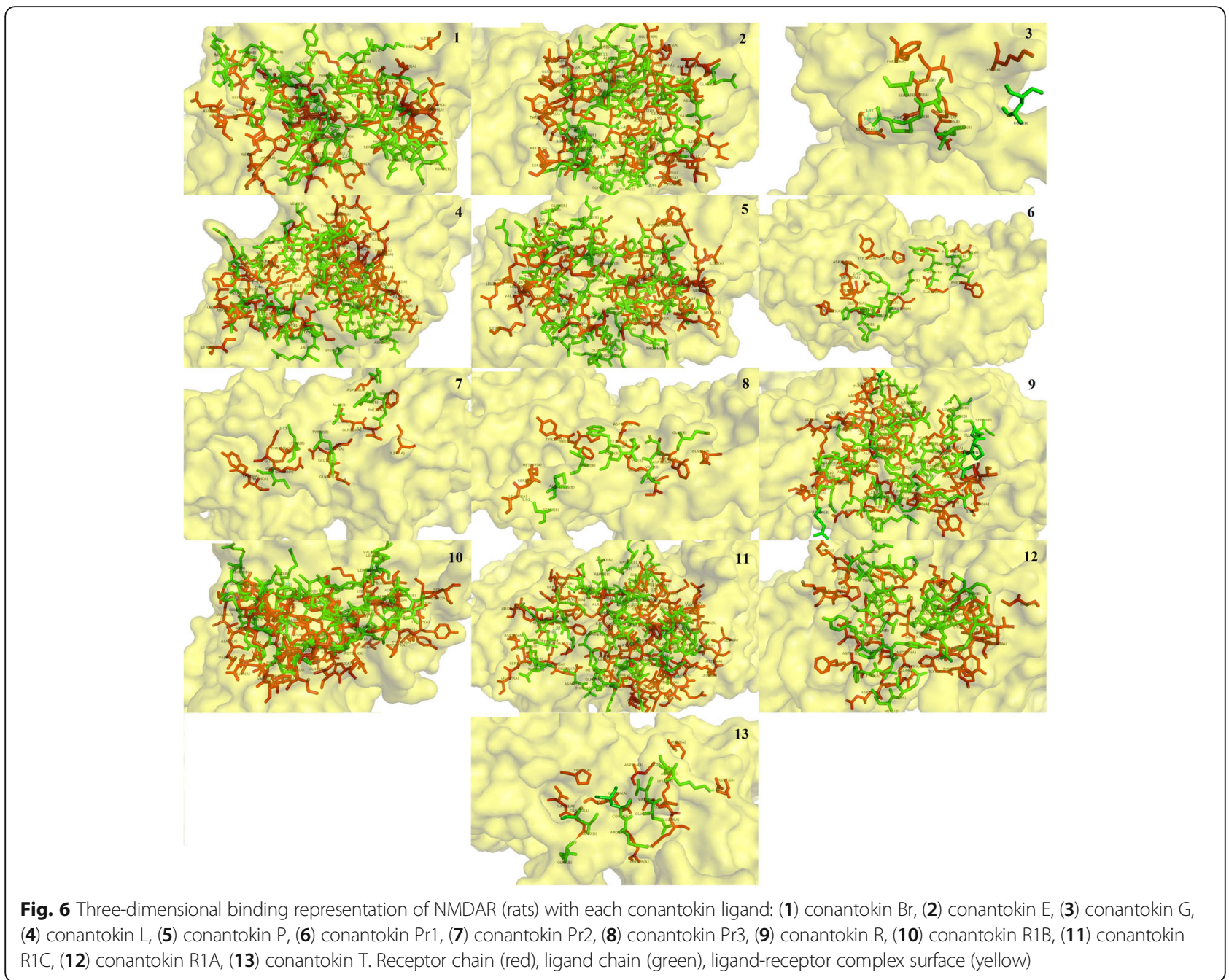

of all the conantokin ligands individually in complex with the NR2B subunit of NMDAR in human are shown in Fig. 4.

It is clear in Fig. 4 that due to difference in sizes and structure, each conantokin occupies the binding site on NMDAR in humans in its own respective orientation to form the most stable complex. However, each ligand is shown to bind to the same binding residues as reported. The position of binding pocket of the NR2B subunit of NMDAR in humans resided by conantokins is shown in Fig. 5. It is shown clearly that all the ligands occupied the same binding pocket in structure of NMDAR as they showed binding with the same residues that have been reported.

Similar binding pattern was observed for the NR2B subunit of NMDAR in rat. Table 3 shows the binding information for NMDAR in rats, highlighting residues involved in hydrogen bonding, their atoms and their bond distances, along with the hydrophobic residues for both the receptor and the ligands.
It has been observed that likewise for human NR2B, Glu236 and Gln110 residues of NR2B subunit in rats were found interacting with the residues of every conantokin ligand. Ile111, Phe114 and Pro177 were mostly found in hydrophobic interactions. This binding pattern was conserved among all the conantokins showing their similarity in potency for the NR2B subunit. The binding pattern of all conantokins for NMDAR in rats is shown in Fig. 6.

The binding pocket of conantokins with the receptor is highlighted in Fig. 7. As in the case of NMDAR in rats, Fig. 7 clearly demonstrates that each conantokin occupies the same binding pocket as NMDAR in humans.

\section{Energy values}

The overall stability of a complex is directly associated with the free energy of that complex. Lower energy values suggest the presence of a high binding affinity between the ligand and the receptor. It is of substantial importance to highlight each complex's free energy in order to evaluate the successful complex formation. The 


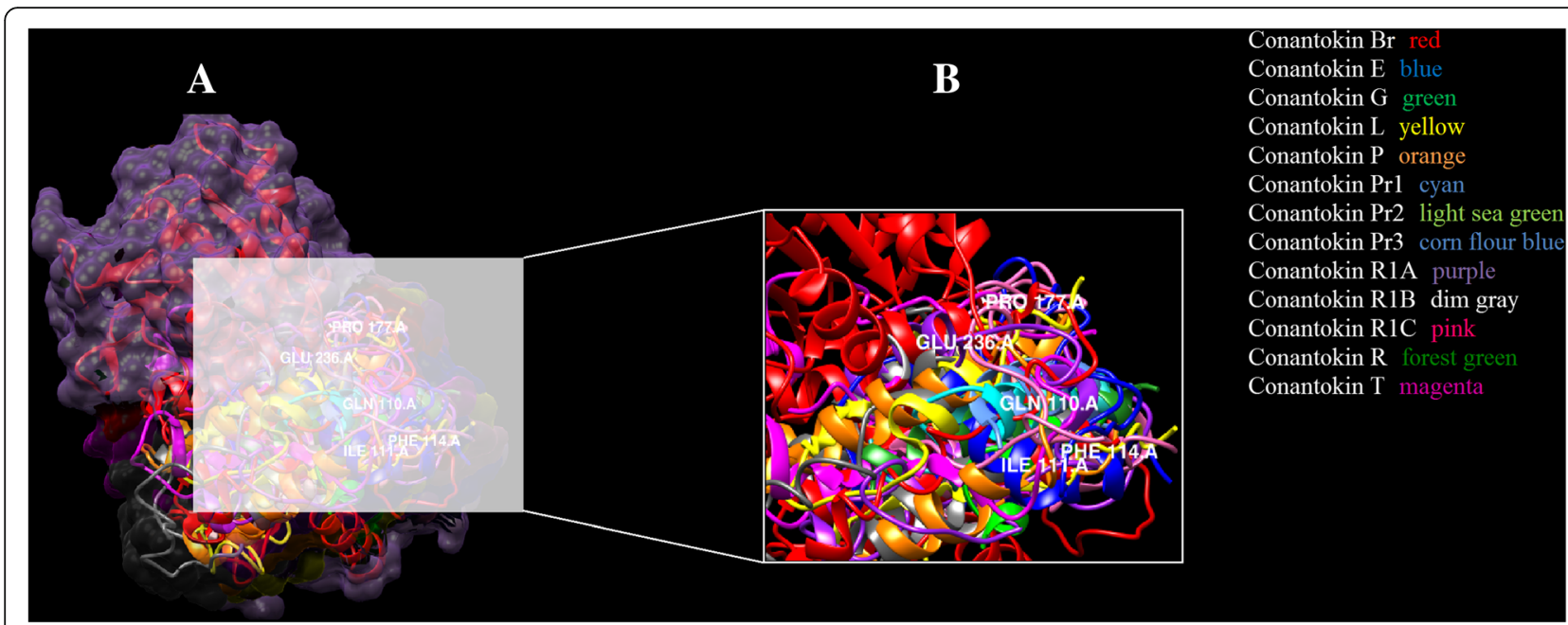

Fig. 7 a Conantokins in complex with the NMDAR (rats). b Active residues in the binding pocket highlighted (white) of NMDAR with conantokin ligands. Three-dimensional binding representation of all toxins from the ligand dataset: conantokin $\mathrm{Br}$ (red), conantokin E (blue), conantokin G (green), conantokin L (yellow), conantokin P (orange), conantokin Pr1 (cyan), conantokin Pr2 (light sea green), conantokin Pr3 (cornflour blue), conantokin R1A (purple), conantokin R1B (dim gray), conantokin R1C (pink), conantokin R (forest green), conantokin T (magenta) with the NMDA receptor in rats

successive energy values for the ligand-receptor complex formed by each toxin with the NMDA receptor in both humans and rats are shown in Fig. 8.

The energy values for all the complexes fall below the value of 0 , as clearly observed from the graphical representation. This suggests the formation of relatively stable complexes between NMDA receptor in both rats and humans with all conantokins. NMDAR in humans showed most affinity for conantokin $\mathrm{P}$, conantokin $\mathrm{E}$, conantokin $\mathrm{R}$ and conantokin Pr3, whereas NMDAR in rats showed more affinity for Conantokin $\mathrm{Br}$ and Conantokin Pr3.

\section{Comparison of reported residues for NMDAR to docking results}

A comparative analysis was performed of the docking results of NMDA receptors in both humans and rats with all the conantokins. The reported residues were inspected to verify if the docking results of this study were indeed in line with the reported information regarding the binding site residues of NR2B subunit of NMDAR. It is clearly displayed in Table 4 that the binding site residues of NMDAR reported in the literature were achieved in the docking experiments for both humans and rats.

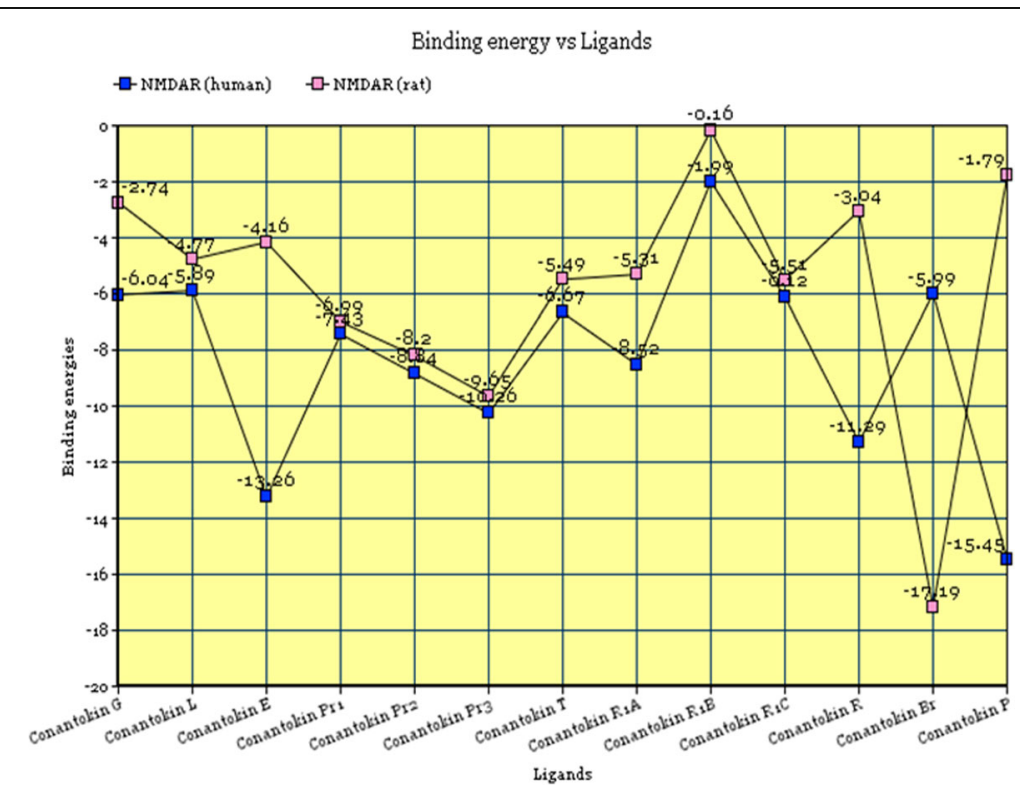

Fig. 8 Graphical plot of binding energies versus toxin ligands 
Table 4 Comparative tabulation of binding residues of reported NMDAR versus post-docking results

\begin{tabular}{lll}
\hline $\begin{array}{l}\text { Reported NMDAR } \\
\text { binding site residues }\end{array}$ & $\begin{array}{l}\text { Docking NMDAR } \\
\text { binding residues (rat) }\end{array}$ & $\begin{array}{l}\text { Docking NMDAR binding } \\
\text { residues (human) }\end{array}$ \\
\hline Gln110 & Gln110 & Gln110 \\
Ile111 & Ile111 & lle111 \\
Phe114 & Phe114 & Phe114 \\
Pro177 & Pro177 & Pro177 \\
Glu236 & Glu236 & Glu236 \\
\hline
\end{tabular}

\section{Conclusions}

Conantokins had been reported as selective antagonists of NR2B subtype of the NMDA receptor. The NR2B subunit is directly involved in the excitotoxicity caused by the over-exposure to glutamate neurotransmitter. Therefore, inhibiting its activity has become a possible target for treatment of Alzheimer's. We designed an in silico study and analysis of the binding interaction of conantokins with the NMDA receptor in both humans and rats. After the binding site residues for the receptors were understood, docking studies were performed and the residues achieved via docking were compared to the binding residues reported in the literature. The similarity of the results suggests the potential successful binding of the toxin ligands with both the receptors, and their subsequent function as their antagonists. Our results helped us to demonstrate the potential of these receptors in complex with the conantokins for the symptomatic treatment of Alzheimer's patients.

\section{Abbreviations}

CNS: Central nervous system; MSA: Multiple sequence alignment; NMDA: Nmethyl-D-aspartate; NMDAR: NMDA receptor; NR2B: N-methyl D-aspartate receptor subtype 2B; RSCB: Research collaboratory for structural bioinformatics; RSMD: Root mean square deviation; SAVES: Structure analysis and verification server

\section{Acknowledgements}

The authors would like to thank the facilities provided by the Department of Biosciences, COMSATS Institute of Information Technology, Pakistan.

\section{Funding}

Not applicable

\section{Authors' contributions}

MW conducted the research and prepared the draft. SB developed the study concept and refined the draft. Both authors read and approved the final manuscript.

\section{Ethics approval and consent to participate}

Not applicable

\section{Consent for publication}

Not applicable

\section{Competing interests}

Both authors declare that they have no competing interests.

\section{Publisher's Note}

Springer Nature remains neutral with regard to jurisdictional claims in published maps and institutional affiliations.

Received: 6 April 2017 Accepted: 13 September 2017

Published online: 20 September 2017

\section{References}

1. Blanke ML, VanDongen AMJ. Activation mechanisms of the NMDA receptor. In: Van Dongen AM, editor. Biology of the NMDA receptor. Boca Raton (FL): CRC Press; 2009

2. Li ST, Ju JG. Functional roles of synaptic and extrasynaptic NMDA receptors in physiological and pathological neuronal activities. Curr Drug Targets. 2012;13(2):207-21.

3. Hunt DL, Castillo PE. Synaptic plasticity of NMDA receptors: mechanisms and functional implications. Curr Opin Neurobiol. 2012;22(3):496-508.

4. Martin SJ, Grimwood PD, Morris RG. Synaptic plasticity and memory: an evaluation of the hypothesis. Annu Rev Neurosci. 2000;23:649-711.

5. Loftis JM, Janowsky A. The N-methyl-D-aspartate receptor subunit NR2B: localization, functional properties, regulation, and clinical implications. Pharmacol Ther. 2003;97(1):55-85.

6. Yang JL, Sykora P, Wilson DM, Mattson MP, Bohr VA. The excitatory neurotransmitter glutamate stimulates DNA repair to increase neuronal resiliency. Mech Ageing Dev. 2011;132(8-9):405-11.

7. Farlow MR. NMDA receptor antagonists. A new therapeutic approach for Alzheimer's disease. Geriatrics. 2004:59(6):22-7.

8. Danysz W, Pasons CG. Alzheimer's disease, $\beta$-amyloid, glutamate, NMDA receptors and memantine-searching for the connections. Br J Pharmacol. 2012;167(2):324-52.

9. Servent D, Blanchet G, Mourier G, Marquer C, Marcon E, Fruchart-Gaillard C. Muscarinic toxins. Toxicon. 2011;58(6-7):455-63.

10. Wagar $\mathrm{M}$, Batool $\mathrm{S}$. In silico analysis of binding of neurotoxic venom ligands with acetylcholinesterase for therapeutic use in treatment of Alzheimer's disease. J Theor Biol. 2015;372:107-17.

11. Waqar M, Kamal MA, Batool S. In silico analysis of binding interaction of mamba toxins with M4 and M2 muscarinic acetylcholine receptors for therapeutic use in Alzheimer's disease. CNS Neurol Disord Drug Targets. 2015;14(8):1031-40.

12. Amin SA, Bhattacharya P, Basak S, Gayen S, Nandy A, Saha A Pharmacoinformatics study of Piperolactam a from Piper Betle root as new lead for non steroidal anti fertility drug development. Comput Biol Chem. 2017:67:213-24.

13. Amin SA, Adhikari N, Agrawal RK, Jha T, Gayen S. Possible binding mode analysis of Pyrazolo-triazole hybrids as potential anticancer agents through validated molecular docking and 3D-QSAR modeling approaches. Letters in Drug Design \& Discovery. 2017;14(5):515-27. www.eurekaselect.com/145590

14. Amin SA, Bhargava S, Adhikari N, Gayen S, Jha T. Exploring pyrazolo [3, 4-d] pyrimidine phosphodiesterase 1 (PDE1) inhibitors: a predictive approach combining comparative validated multiple molecular modelling techniques. J Biomol Struct Dyn. 2017;13:1-19.

15. Schwede T, Kopp J, Guex N, Peitsch MC. SWISS-MODEL: an automated protein homology-modeling server. Nucleic Acids Res. 2003;31(3):3381-5.

16. Karakas E, Simorowski N, Furukawa $\mathrm{H}$. Structure of the zinc-bound amino-terminal domain of the NMDA receptor NR2B subunit. EMBO J. 2009;28(24):3910-20.

17. Berman HM, Westbrook J, Feng Z, Gilliland G, Bhat TN, Weissig H, et al. The Protein Data Bank. Nucleic Acids Res. 2000;28(1):235-42.

18. Laskowski RA, Rullmannn JA, MacArthur MW, Kaptein R, Thornton JM. AQUA and PROCHECK-NMR: programs for checking the quality of protein structures solved by NMR. J Biomol NMR. 1996;8(4):477-86.

19. Colovos C, Yeates TO. Verification of protein structures: patterns of nonbonded atomic interactions. Protein Sci. 1993;2(9):1511-9.

20. Bowie JU, Lüthy $R$, Eisenberg $D$. A method to identify protein sequences that fold into a known three-dimensional structure. Science. 1991;253(5016):164-70.

21. Lebbe EKM, Tytgat J. In the picture: disulfide-poor conopeptides, a class of pharmacologically interesting compounds. J Venom Anim Toxins incl Trop Dis. 2016;22:30. doi: 10.1186/s40409-016-0083-6.

22. Roy A, Kucukural A, Zhang Y. I-TASSER: a unified platform for automated protein structure and function prediction. Nat Protoc. 2010;5(4):725-38. 
23. Simossis VA, Heringa J. PRALINE: a multiple sequence alignment toolbox that integrates homology-extended and secondary structure information. Nucleic Acids Res. 2005;33:W289-94.

24. Teichert RW, Jimenez EC, Twede V, Watkins M, Hollmann M, Bulaj G, et al. Novel conantokins from Conus parius venom are specific antagonists of $\mathrm{N}$ methyl-D-aspartate receptors. J Biol Chem. 2007;282(51):36905-13.

25. Nielsen K, Skjaerbaek N, Dooley M, Adams DA, Mortensen M, Dodd PR, et al. Structure-activity studies of conantokins as human N-methyl-D-aspartate receptor modulators. J Med Chem. 1999;42(3):415-26.

26. Sheng Z, Prorok M, Castellino FJ. Specific determinants of conantokins that dictate their selectivity for the NR2B subunit of N-methyl-D-aspartate receptors. Neuroscience. 2010;170(3):703-10.

27. Lengauer T, Rarey M. Computational methods for biomolecular docking. Curr Opin Struct Biol. 1996;6(3):402-6.

28. Mondal C, Halder AK, Adhikari N, Saha A, Saha KD, Gayen S, et al. Comparative validated molecular modeling of p53-HDM2 inhibitors as antiproliferative agents. Eur J Med Chem. 2015;90:860-75.

29. Morris GM, Huey R, Lindstrom W, Sanner MF, Belew RK, Goodsell DS, et al. AutoDock4 and AutoDockTools4: automated docking with selective receptor flexiblity. J Comput Chem. 2009;30(16):2785-91.

30. Pettersen EF, Goddard TD, Huang CC, Couch GS, Greenblatt DM, Meng EC, et al. UCSF chimera-a visualization system for exploratory research and analysis. J Comput Chem. 2004;25(13):1605-12.

31. Wallace AC, Laskowski RA, Thornton JM. LIGPLOT: a program to generate schematic diagrams of protein-ligand interactions. Protein Eng. 1995;8(2):127-34.

32. DeLano WL. Pymol: An open-source molecular graphics tool. CCP4 Newsletter On Protein Crystallography. 2002;40:82-92.

\section{Submit your next manuscript to BioMed Central and we will help you at every step:}

- We accept pre-submission inquiries

- Our selector tool helps you to find the most relevant journal

- We provide round the clock customer support

- Convenient online submission

- Thorough peer review

- Inclusion in PubMed and all major indexing services

- Maximum visibility for your research

Submit your manuscript at www.biomedcentral.com/submit
Biomed Central 